\title{
PERLINDUNGAN HUKUM TERHADAP HAK ASASI ANAK YANG MENJADI KORBAN KEKERASAN Zuraidah $^{*}$ Muhamad Sadi Is ${ }^{\dagger}$
}

\begin{abstract}
Child rights are an integral part of human rights so that the government must develop the obligation to protect, fulfill and respect the rights of children especially the rights of children who are victims of violence, because violence against children especially in Indonesia is increasing recently. Therefore, the form of legal protection against the rights of children who are victims of violence can be given in a repressive form that is done in a systematic way, through a series of programs, stimulation, training, education, prayer guidance, games and can also be provided through legal aid called advocacy and child protection laws. While the concept of legal protection of child rights in the future must do law reform of child protection system in Indonesia with the aim to give justice, certainty and benefit to children in Indonesia in particular so as to protect and guarantee the rights of children who become victims violence. In order for child protection law in Indonesia in the future to be able to really give protection to child rights which become victims of violence, then child protection law must be free from humanity principle based on human rights.
\end{abstract}

Kata Kunci: Perlindungan Hukum, Hak Asasi Anak, Korban Kekerasan.

Serangkaian kekerasan yang dilakukan kepada anak dapat merusak masa depan anak, atau setidak-tidaknya hal tersebut akan membekas dalam jiwa kanak-kanaknya hingga ia beranjak dewasa. Sehingga dikemudian hari jangan salahkan mereka, apabila mereka cenderung melakukan hal-hal yang menyimpang, karena apa yang mereka rasakan atau apa yang mereka saksikan dahulu akan mereka terapkan ketika mereka dewasa kelak. Termasuk juga tindakan kekerasan secara seksual yang dialami oleh anak-anak pun akan juga memberikan dampak negatif kepada masa depan mereka (Antoni, 2015: 29).

Sehingga diperlukan perlindungan hukum yang dapat diberikan pada anak-anak harus memiliki jangkauan yang luas, hal ini dapat dilihat dari berbagai dokumen dan pertemuan tingkat internasional yang menginginkan pentingnya perlindungan hukum bagi anak yang meliputi berbagai aspek yaitu: (a), perlindungan terhadap hak-hak asasi dan kebebasan anak, (b) perlindungan anak dalam proses

*Fakultas Syariah dan Hukum UIN Raden Fatah Palembang, alamat koresponden penulis, email: zuraidah_uin@radenfatah.ac.id.

†Fakultas Hukum Universitas Sriwijaya Palembang, alamat koresponden penulis, email: m.sadiis_uin@radenfatah.ac.id. 
peradilan, (c) perlindungan kesejahteraan anak (dalam lingkungan keluarga, pendidikan dan lingkungan sosial), (d) perlindungan anak dalam masa penahanan dan perampasan kemerdekaan, (e) perlindungan anak dari segala eksploitasi (perbudakan, perdagangan anak, pelacuran, pornografi, perdagangan/ penyalahgunaan obatobatan, memperalat anak dalam melakukan kejahatan dan sebagainya), (f) perlindungan terhadap anak-anak jalanan, (g) perlindungan anak dari akibat-akibat peperangan atau konflik bersenjata, (h) perlindungan anak terhadap tindakan kekerasan. (Barda Nawawi Arief, 1998: 156).

Anak merupakan bagian dari generasi mudah sebagai salah satu sumber daya manusia yang merupakan potensi dan penerus cita perjuangan bangsa, yang memiliki peranan startegis dan mempunyai ciri dan sifat khusus, memerlukan pembinaan dan perlindungan dalam rangka menjamin pertumbuhan dan perkembangan fisik, mental, dan sosial secara utuh, serasi selaras dan seimbang. Untuk melaksanakan pembinaan dan memberikan perlindungan terhadap anak, diperlukan dukungan, baik yang menyangkut kelembagaan maupun perangkat hukum yang lebih mantap dan memadai, dan oleh karena itu ketentuan mengenai penyelenggaraan pengadilan bagi anak perlu dilakukan secara khusus (Mohammad Taufik Makarao, 2013: 1).

Hak-hak anak merupakan bagian integral dari Hak Asasi Manusia berkaitan dengan peranan negara, maka tiap negara mengembankan kewajiban untuk melindungi, memenuhi, dan menghormati hak-hak anak, Berdasarkan kewajiban negara dimaksud maka sistem kesejahteraan anak dan keluarga diimplementasikan dalam kerangka kebijakan yang sifatnya kontinum dan tingkat makro sampai mikro (Mohammad Taufik Makarao, 2013: 31). Karena anak sebagai makhluk sosial juga sebagai makhluk individual, artinya bahwa tiap-tiap anak itu merupakan pribadi yang khas menurut corak kepribadiannya (W.A.Gerungan, 2002: 23), maka sangat diperlukan perlindungan terhadap anak baik dilakukan oleh orang tuanya maupun oleh pemerintah, karena masa depan anak merupakan masa depan bangsa. Jangan sampai anak-anak menjadi korban kekerasan baik dilakukan oleh keluarga sendiri maupun dilakukan oleh orang disekitar lingkungan atau masyarakat pada umumnya yang dapat membuat anak menjadi kehilangan masa depannya.

Pada hakikatnya Hak Asasi Manusia tidak membedakan hakhak asasi dari sudut jenis kelamin (perempuan atau laki-laki). Keduaduanya adalah manusia yang mempunyai hak asasi yang sama (Barda Nawawi Arief, 2007: 65). Negara kita pun menjamin hak perempuan tanpa diskriminasi. Dalam Penjelasan Undang-Undang Dasar Negara Republik Indonesia Tahun 1945 disebutkan bahwa Negara Indonesia adalah negara yang berdasarkan atas hukum (Rechtsstaat) tidak berdasarkan atas kekuasaan belaka (Machtsstaat). Sebagai negara 
hukum, salah satu cirinya adalah adanya jaminan dan perlindungan terhadap hak-hak asasi manusia dalam segala segi kehidupan bermasyarakat dan bernegara, karena pada dasarnya hak-hak asasi manusia merupakan karunia dari Tuhan Yang Maha Esa dan senantiasa melekat pada kehidupan dan keberadaban manusia itu sendiri. Hal ini tercermin dalam Pembukaan Undang-Undang Dasar Negara Republik Indonesia Tahun 1945 yang menjiwai keseluruhan pasal yang tersusun dalam Batang Tubuh Undang-Undang Dasar Negara Republik Indonesia Tahun 1945, terutama yang berkaitan dengan Pasal 27 ayat (1) mengatur tentang "Segala warga negara bersamaan kedudukannya di dalam hukum dan pemerintahan dan wajib menjunjung tinggi hukum dan pemerintahan itu dengan tidak ada kecualinya". Bunyi pasal tersebut, dapat diartikan sebagai bentuk hak asasi setiap orang atas pengakuan, jaminan, perlindungan, keadilan, dan perlakuan yang sama di hadapan hukum dan pemerintah.

Hukum pada dasarnya merupakan pencerminan dari Hak Asasi Manusia, sehingga hukum itu mengandung keadilan atau tidak, ditentukan oleh Hak Asasi Manusia yang dikandung dan diatur atau dijamin oleh hukum itu. Hukum tidak lagi dilihat sebagai refleksi kekuasaan semata-mata, tetapi juga harus memancarkan perlindungan terhadap hak-hak warga negara (Unbanunaek Mimi, et al, 1995: 45). Kepekaan akan rasa keadilan dan sikap peduli terhadap generasi penerus suatu bangsa hendaknya diukur pula dari perhatian mereka terhadap usaha-usaha perlindungan hakhak anak yang bermasalah dengan hukum. Dalam proses peradilan pidana anak, anak-anak ini tidak mengetahui hak dan kewajibannya, karena itu perlu mendapat bantuan dan perlindungan terhadap pelaksanaan hak dan kewajiban anak secara seimbang dan manusiawi (Unbanunaek Mimi, et al, 1995: 47).

Menurut Made Sadhi Astuti ada beberapa hak anak yang perlu diperhatikan dan diperjuangkan pelaksanaannya bersama-sama. Anak-anak mempunyai hak antara lain: tidak menjadi korban dalam proses peradilan pidana; mempunyai kewajiban sebagai hak untuk ikut serta menegakkan keadilan dalam suatu proses peradilan pidana sesuai dengan kemampuan mereka masing-masing untuk dibina agar mampu melaksanakan kewajibannya sebagai warga negara, anggota masyarakat yang baik oleh yang berwajib dalam arti luas; untuk melaksanakan kewajiban membina, mendampingi rekan-rekan sebayanya untuk melaksanakan hak dan kewajiban mereka secara rasional positif, bertanggungjawab dan bermanfaat dalam proses tersebut (Abintoro Prakoso, 2013: 21).

Upaya perlindungan anak perlu dilaksanakan sedini mungkin, yakni sejak dari janin dalam kandungan sampai anak berumur 18 (delapan belas) tahun. Bertitik tolak dari konsepsi perlindungan anak yang utuh, menyeluruh, dan komprehensif, undang-undang ini 
meletakkan kewajiban memberikan perlindungan kepada anak berdasarkan asas-asas sebagai berikut: a). nondiskriminasi; b). kepentingan yang terbaik bagi anak; c). hak untuk hidup, kelangsungan hidup, dan perkembangan; dan d). penghargaan terhadap pendapat anak. Ditinjau dari sifat perlindungannya, perlindungan anak dapat dibedakan menjadi perlindungan yang bersifat yuridis, meliputi perlindungan dalam bidang hukum perdata dan hukum pidana, dan perlindungan yang bersifat non yuridis, meliputi perlindungan di bidang sosial dan bidang pendidikan (Maulana Hassan Waddong, 2000: 40).

Berdasarkan uraian di atas maka peneliti tertarik untuk melakukan penelitian dengan judul "Perlindungan Hukum Terhadap Hak Asasi Anak yang Menjadi Korban Kekerasan”. Dengan rumusan sebagai berikut: pertama; bagaimanakah bentuk perlindungan hukum terhadap hak asasi anak yang menjadi korban kekerasan?. Kedua; bagaimanakah konsep perlindungan hukum terhadap hak asasi anak di masa yang akan datang?

\section{Bentuk Perlindungan Hukum Terhadap Hak Asasi Anak Korban Kekerasan}

Bentuk perlindungan hukum terhadap hak asasi anak yang menjadi korban kekerasan diatur dalam Naskah Akademik Rancangan Undang-Undang Sistem Peradilan Pidana Anak, akan tetapi kekerasan terhadap anak di Indonesia sampai sekarang ini belum bisa diatasi secara maksimal karena masih sering terjadi berbagai macam kekerasan terhadap anak. Adapun kekerasan terhadap anak tersebut dapat diklasifikasi sebagai berikut: pertama; Kekerasan fisik, bentuk ini paling mudah dikenali. Terkategorisasi sebagai kekerasan ini adalah menampar, menendang, memukul/meninju, mencekik, mendorong menggigit, membenturkan, mengancam dengan benda tajam dan sebagainya; kedua; kekerasan psikis, kekerasan jenis ini tidak begitu mudah untuk dikenali. Akibat yang dirasakan oleh korban tidak memberikan bekas yang tampak jelas bagi orang lain. Dampak kekerasan ini akan berpengaruh pada situasi perasaan tidak aman dan nyaman, menurunnya harga diri serta martabat korban. Jenis kekerasan seksual, termasuk dalam kategori ini adalah segala tindakan yang muncul dalam bentuk paksaan atau ancaman untuk melakukan hubungan seksual, melakukan penyiksaan atau bertindak sadis serta meninggalkan seseorang atau termasuk mereka yang tergolong masih usia anak-anak setelah melakukan hubungan seksual; ketiga; kekerasan ekonomi, kekerasan jenis ini sangat sering terjadi dalam lingkungan keluarga. Pada anak-anak kekerasan jenis ini sering terjadi ketika orang tua memaksa anak yang masih berusia di bawah umur untuk dapat memberikan kontribusi ekonomi keluarga, sehingga fenomena penjual korban, pengamen jalanan, pengemis 
anak, dan lain-lain kian merebak terutama di perkotaan (Bagong Suyanto, 2016: 29-30).

Dengan demikian maka anak yang menjadi korban kekerasan harus diberikan perlindungan hukum terutama mengenai hak asasi anaknya. Karena perlindungan hukum hak asasi anak adalah meletakan hak asasi anak dalam status sosial anak dalam kehidupan masyarakat sebagai bentuk perlindungan terhadap kepentingankepentingan anak yang mengalami kekerasan atau masalah sosial. Perlindungan hak asasi anak dapat diberikan dalam berbagai cara. Perlindungan hak asasi anak diberikan dengan cara sistematis, melalui serangkaian program, stimulasi, latihan, pendidikan, bimbingan shalat, permainan dan dapat juga diberikan melalui bantuan hukum yang dinamakan advokasi dan hukum perlindungan anak (Maulana Hassan Wadong, 2000: 36).

Perlindungan hukum terhadap hak asasi anak yang menjadi korban kekerasan tidak bisa lepas dari pengaruh penegakan hukum (Derita Prapti Rahayu, 2014: 34). Penegakan hukum dalam kerangka negara hukum Republik Indonesia, undang-undang tertulis maupun hukum tidak tertulis yang akan diterapkan dalam mengadili kasus anak yang berkonflik dengan hukum tidak boleh bertentangan dengan ideologi negara, yaitu Pancasila dan Undang-Undang Dasar Negara Republik Indonesia Tahun 1945 sebagai puncak hirarki perundangundangan yang ada di Indonesia (Syarif Mappiasse, 2015: 102). Artinya perlindungan hukum dapat diberikan apabila penegakan hukumnya melakukannya sesuai dengan nilai-nilai Pancasila dan Undang-Undang Dasar Negara Republik Indonesia Tahun 1945 kemudian dilakukan secara profesional dan sesuai dengan peraturan perundang-undangan yang berlaku khususnya peraturan perundangundangan mengenai anak. Karena sekarang ini penegakan hukum di Indonesia dianggap belum bisa memberikan perlindungan hukum secara maksimal, sebagaimana yang dikemukakan oleh Saldi Isra bahwa masih terjadinya karut marut wajah penegak hukum di Indonesia, padahal carut marutnya wajah penegakan hukum ini dapat menyebabkan masalah subtansi hukum sehingga dapat menciptakan subtansi hukum yang lemah, kalau subtansi hukumnya lemah maka tidak hanya memudahkan melakukan segala macam bentuk penyimpangan, tetapi juga memberikan kesempatan luas kepada penegak hukum untuk "menggorengnya" sesuai dengan kepentingan masing-masing (Saldi Isra, 2016: 5-6).

Penegakan hukum yang bisa memberikan perlindungan hukum khususnya perlindungan hukum hak asasi anak, maka penegak hukum harus menjalankan hukum harus memperhatikan prinsipprinsip bahwa menjalankan atau menegakan hukum tidak sama dengan menerapkan huruf-huruf peraturan begitu saja, tetapi mencari dan menemukan makna sebenarnya dari suatu peraturan dengan kecerdasan spiritual yang dimiliki oleh penegak hukum, yaitu: 
pertama; penggunaan kecerdasan spiritual untuk bangun dari keterpurukan hukum memberi pesan penting kepada kita untuk berani mencari jalan baru (rule breaking) dan tidak membiarkan diri terkekang menjalankan hukum lama dan tradisional yang jelas-jelas lebih banyak melukai rasa keadilan dalam masyarakat khususnya rasa keadilan terhadap anak. Kedua; pencarian makna lebih dalam hendaknya menjadi ukuran baru dalam menjalankan hukum dan bernegara hukum, apa makna peraturan, prosedur, asas, doktrin dan lainnya. Ketiga; hukum hendaknya dijalankan tidak menurut prinsip logika saja tetapi dengan perasaan, kepedulian dan semangat keterlibatan (compassion) kepada bangsa (Satjipto Rahardjo, 2006: 22).

Islam melindungi hak-hak untuk hidup, merdeka, merasa aman, dilarang untuk bunuh diri, dan pembunuhan. Dalam Islam pembunuhan terhadap seorang manusia tanpa alasan yang benar diibaratkan sama dengan membunuh seluruh umat manusia. Islam juga menyelamatkan nasib para budak, hal tersebut telah dibuktikan dalam sejarah perkembangan Islam (Henny Nuraeny, 2011: 3-4). Dengan demikian dapat tercapai tujuan dari perlindungan anak adalah untuk menjamin terpenuhinya hak-hak anak agar dapat hidup, tumbuh, berkembang, dan berpartisipasi secara optimal sesuai dengan harkat dan martabat kemanusiaan, serta mendapat perlindungan dari kekerasan dan diskriminasi, demi terwujudnya anak Indonesia yang berkualitas, berakhlak mulia, dan sejahtera. Dalam perlindungan ini mengandung aspek-aspek penting sebagai berikut: pertama; terjamin dan terpenuhinya hak-hak anak; kedua; terpenuhinya harkat dan martabat kemanusiaan; ketiga; perlindungan anak dari kekerasan dan diskriminasi; dan keempat; terwujudnya anak yang berkualitas, berakhlak mulia, dan sejahtera. (Bambang Waluyo, 2017: 70). Oleh karena itu, perlindungan terhadap hak asasi anak yang menjadi korban kekerasan diatur dalam Pasal 89-91 Undang-Undang Republik Indonesia Nomor 11 Tahun 2012 tentang Sistem Peradilan Pidana Anak.

\section{Konsep Perlindungan Hukum Terhadap Hak Asasi Anak}

Anak adalah masa depan suatu bangsa, oleh karena itu perlu dibina dan dilindungi agar kelak anak-anak tersebut tumbuh menjadi manusia pembangunan yang berkualitas tinggi. Salah satu cara pembinaan dan perlindungan adalah dengan adanya hukum. (Syafruddin Hasibuan (ed), tth: 78). Peraturan yang telah ada yang diharapkan mampu memberikan perlindungan terhadap anak pada kenyataannya masih belum menggembirakan. Nasib anak yang berkonflik dengan hukum belum seindah ungkapan verbal yang seringkali kerap kita dengar memposisikan anak bernilai, penting, penerus masa depan bangsa dan sejumlah simbolik lainnya. Hak-hak anak sebagaimana dimaksud dalam dokumen hukum mengenai perlindungan hak-hak anak masih belum cukup ampuh bisa 
menyingkirkan keadaan yang buruk bagi anak. Penegakan hak-hak anak sebagai manusia dan anak sebagai anak ternyata masih memprihatinkan. problematika anak sampai saat ini belum menarik banyak pihak untuk membelanya. Kenyataannya, tatanan dunia dan perilaku kehidupan masyarakat masih menyimpan masalah anak (Muhammad Joni dan Zulchaina Z Tanamas, 1999: 1).

Padahal yang menjadi dasar pelaksanaan perlindungan anak di Indonesia adalah: pertama; dasar Filosofis, Pancasila dasar kegiatan dalam berbagai bidang kehidupan keluarga, bermasyarakat, bernegara, dan berbangsa, serta dasar filosofis pelaksanaan perlindungan anak; kedua; dasar Etis, pelaksanaan perlindungan anak harus sesuai dengan etika profesi yang berkaitan, untuk mencegah perilaku menyimpang dalam pelaksanaan kewenangan, kekuasaan, dan kekuatan dalam pelaksanaan perlindungan anak, dan ketiga; dasar Yuridis, pelaksanaan perlindungan anak harus didasarkan pada Undang-Undang Dasar Negara Republik Indonesia Tahun 1945 dan berbagai peraturan perundang-undangan lainnya yang berlaku. Penerapan dasar yuridis ini harus secara integratif, yaitu penerapan terpadu menyangkut peraturan perundang-undangan dari berbagai bidang hukum yang berkaitan.(Romli Atmasasmita, (ed), 1997: 53).

Keberadaan undang-undang Pengadilan anak masih banyak kelemahan, baik secara substantif maupun proses peradilannya. Masalah substantif diantaranya masalah batasan usia anak yang dapat diajukan ke sidang anak, yang mendorong beberapa orang melakukan uji material undang-undang pengadilan anak tersebut ke Mahkamah Konstitusi. Sedangkan Paulus Hadi Suprapto berpendapat bahwa undang-undang pengadilan anak tidak mengatur mengenai diversi. Ketentuan undang-undang pengadilan anak mengandung beberapa kelemahan diantaranya: struktur dan kedudukan peradilan anak. Dalam Pasal 2 Undang-Undang Republik Indonesia Nomor 11 Tahun 2012 tentang Sistem Pengadilan Pidana Anak dinyatakan Pengadilan Anak adalah pelaksana kekuasaan kehakiman yang berada di lingkungan peradilan umum. tidak adanya undang-undang yang secara khusus mengatur tentang hak-hak anak yang menjadi korban kekerasan atau dari tindak pidana. Perlunya undang-undang yang secara khusus mengatur hak-hak anak yang menjadi korban kekerasan.

Sebagaimana diketahui bahwa akhir-akhir ini tindak pidana yang menjadi anak sebagai korbannya, cenderung meningkat. Di berbagai media masa sering muncul pemberitaan mengenai pelanggaran kesusilaan dan kekerasan terhadap anak, hingga eksploitasi anak-anak di bawah umur sebagai pekerja seks dan pengemis/gelandangan. Dalam hal yang demikian pun hukum pidana diharapkan dapat memberikan perlindungan yang memadai sesuai dengan tujuan untuk mensejahterahkan anak dalam menyongsong 
masa depannya, termasuk pada anak yang terlibat dalam kasus pidana sekalipun bukan sebagai pelaku atau sebagai korban, misalnya sebagai saksi dalam proses peradilan pidana (Al. Wisnubroto, 2013: 2).

Hak asasi anak wajib dilindungi oleh semua orang (bukan hanya penegak hukum polisi, hakim, jaksa, dan pengacara) maupun masyarakat pada umumnya. Karena hak anak merupakan bagian hak asasi anak yang wajib dijamin, dilindungi dan dipenuhi oleh semua pihak baik oleh orang tuanya sendiri, keluarganya, masyarakat, maupun pemerintah dan negara. Hak anak wajib dijamin, menjadi lebih luas daripada sekedar perlindungan saja. Karena dengan menjamin, artinya inisiatif untuk aktif harus datang dari pihak yang memberikan jaminan (orang tuanya sendiri, keluarganya, masyarakat, maupun pemerintah dan negara). Nyata dan terang dari ketentuan undang-undang sebagaimana diatur dalam Undang-Undang Republik Indonesia Nomor 11 Tahun 2012 tentang Sistem Pengadilan Pidana Anak. Oleh karena itu, penanganan masalah anak yang bermasalah dengan hukum menjadi satu cara khusus dan yang khas Indonesia sebagaimana dikenal dengan istilah diversi. Diversi ini merupakan pergeseran paradigma mengenai menyelesaikan masalah anak yang bermasalah dengan hukum karena selama ini khususnya di Indonesia belum ada undang-undang yang khusus untuk menyelesaikan masalah anak. Dengan pergeseran paradigma berpikir tersebut diharapkan kedepan dapat menjamin masalah anak yang bermasalah dengan hukum dapat diminimalisir dan dapat menjadi anak yang mempunyai prestasi dan menjadi generasi bangsa yang dapat dihandalkan (Nikolas Simanjuntak, 2009: 337-338).

Upaya memberikan perlindungan hak asasi anak yang menjadi korban kekerasan di Indonesia pada masa yang akan datang dapat dilihat pada gambar di bawah ini:

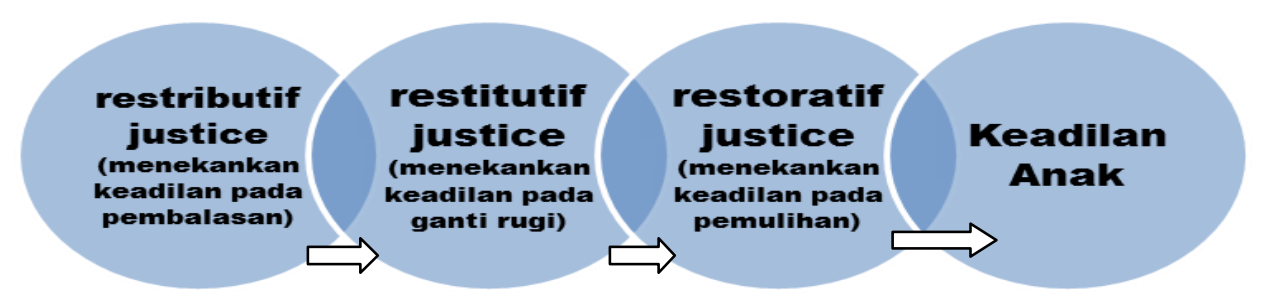

Dengan adanya perlindungan hak asasi anak yang menjadi korban kekerasan diharapkan dengan konsep di atas dapat memberikan rasa keadilan bagi anak yang menjadi korban kekerasan, sehingga anak yang menjadi korban kekerasan secara hukum dapat dipulihkan atau diperbaiki sehingga dapat menjadi generasi bangsa Indonesia yang dapat dihandalkan.

Dalam rangka memberikan perlindungan hukum terhadap hak asasi anak yang menjadi korban kekerasan maka ketentuan hukum khususnya hukum acara wajib dilaksanakan oleh aparat penegakan 
hukum (polisi, jaksa, hakim dan pengacara) dalam menangani masalah anak yang berhadapan dengan hukum dengan menjunjung tinggi hak-hak asasi anak. Kemudian pendamping atau para ahli (pemerhati anak atau lembaga yang konsen terhadap anak) wajib dilibatkan dengan tujuan supaya bisa membantu untuk mengungkapkan keterangan yang otentik, sah, dan akurat mengenai subtansi kebenaran hukum yang dapat diperoleh dari kesaksian yang diberikan oleh anak. Selanjutnya teknis penyelidikan, penyidikan, penuntutan, dan persidangan terhadap anak yang bermasalah dengan hukum harus dilakukan dengan cara yang tidak akan merusak perkembangan kepribadian si anak di kemudian hari. Bahkan jika perlu apabila ada penegak hukum (polisi, jaksa, hakim dan pengacara) dalam proses menyelesaikan masalah anak yang berhadapan dengan tidak menerapkan hal tersebut dapat dikenakan sanksi baik sanksi pidana, maupun dikenakan sanksi administratif sebagaimana dijelaskan pada bagian di atas.

Penegakan hukum (polisi, jaksa, hakim, dan pengacara) khususnya hakim dalam memberikan perlindungan hukum terhadap hak asasi anak yang menjadi korban kekerasan. Hakim harus bisa mengaplikasikan hukum dari yang masih sangat umum dan abstrak digunakan untuk memberikan perlindungan hukum terhadap anak yang menjadi korban kekerasan yang terjadi dalam masyarakat dengan hukum di dalam masyarakat atau membumikan hukum pada suatu pristiwa konkret anak. Karena penerapan hukum tidak bisa hanya sekedar menerapkan undang-undang (Undang-Undang Republik Indonesia Nomor 11 Tahun 2012 tentang Sistem Pengadilan Pidana Anak) atau peraturan hukum tertulis tetapi membutuhkan kreativitas hakim untuk menemukan hukum dari berbagai sumber penemuan hukum dengan menjamin rasa keadilan dan memperjuangkan masa depan anak di Indonesia khusus anak yang menjadi korban kekerasan (Siti Malikhaun Badriyah, 2016: 79).

Penegakan prinsip keadilan adalah salah satu ciri dari negara hukum. Keadilan hak dasar manusia yang sejalan dengan prinsip persamaan di muka hukum. Setiap orang memiliki hak untuk memperoleh pemulihan atas pelanggaran hak yang mereka derita, sedangkan negara memiliki kewajiban untuk memastikan pemenuhan hak-hak tersebut. Akumulasi dari hak-hak tersebut mengafirmasi bahwa keadilan telah menjadi suatu hak asasi manusia yang wajib dihormati dan dijamin pemenuhannya. Ada kebutuhan untuk menempatkan konsep akses terhadap keadilan sebagai suatu affirmative action berdasarkan perspektif hak asasi manusia dengan tujuan bukan untuk menimbulkan suatu diskriminasi terhadap hak asasi manusia khususnya hak asasi anak yang bermasalah dengan hukum (Syamsul Fatoni, 2015: 7-8).

Keadilan merupakan sasaran utama dari hukum, maka penegak hukum haruslah diarahkan, agar tercapai keadilan baik bagi 
individu maupun keadilan bagi masyarakat atau yang dikenal dengan keadilan sosial (Munir Fuady, 2003: 53). Di samping untuk mencapai keadilan, hukum juga mempunyai tujuan untuk menciptakan kepastian hukum bagi manusia pribadi maupun bagi masyarakat luas. Dalam hal ini hukum harus dapat menyelaraskan antara unsur keadilan dan elemen kepastian hukum. Sebab sering kali antara keadilan dan kepastian hukum saling bertentangan satu sama lain. (Munir Fuady, 2003: 56). Selain keadilan dan kepastian hukum juga mempunyai tujuan yaitu untuk memberikan manfaat baik bagi pribadi atau orang perorang maupun bagi masyarakat pada umumnya.

Hukum perlindungan anak di Indonesia khususnnya dalam rangka memberikan perlindungan hak asasi anak yang menjadi korban kekerasan di Indonesia di masa yang akan datang harus melakukan law reform dengan tujuan untuk memberikan keadilan, kepastian, dan kemanfaatan terhadap anak di Indonesia khususnya sehingga dapat melindungi sekaligus menjamin hak-hak asasi anak yang menjadi korban kekerasan. Karena memberikan perlindungan hukum terhadap hak asasi anak yang menjadi korban kekerasan merupakan perlindungan terhadap harkat manusia, sehingga jaminan pemerintah terhadap pelaksanaan hak asasi anak yang menjadi korban kekerasan sudah masuk ke wilayah peradaban umat manusia. Dalam hal ini, hukum dalam dunia yang beradab yaitu hukum yang antara lain melindungi hak asasi terhadap anak yang menjadi korban kekerasan secara maksimal. (Munir Fuady dan Sylvia Laura L. Fuady, 2016: 27). Agar anak dapat hidup, tumbuh, berkembang, dan berpartisipasi secara optimal sesuai dengan harkat dan martabat kemanusiaan, serta mendapat perlindungan dari kekerasan dan diskriminasi.

Negara menjunjung tinggi hak asasi manusia, termasuk di dalamnya hak asasi Anak yang ditandai dengan adanya jaminan perlindungan dan pemenuhan Hak Anak dalam Undang-Undang Dasar Negara Republik Indonesia Tahun 1945 dan beberapa ketentuan peraturan perundang-undangan baik yang bersifat nasional maupun yang bersifat internasional. Jaminan ini dikuatkan melalui ratifikasi konvensi internasional tentang Hak Anak, yaitu pengesahan Konvensi Hak Anak melalui Keputusan Presiden Nomor 36 Tahun 1990 tentang Pengesahan Convention On The Rights Of The Child (Konvensi Tentang Hak-Hak Anak).

Negara, Pemerintah, Pemerintah Daerah, Masyarakat, Keluarga dan Orang Tua berkewajiban untuk memberikan perlindungan dan menjamin terpenuhinya hak asasi Anak sesuai dengan tugas dan tanggung jawabnya. Perlindungan terhadap Anak yang dilakukan selama ini belum memberikan jaminan bagi Anak untuk mendapatkan perlakuan dan kesempatan yang sesuai dengan kebutuhannya dalam berbagai bidang kehidupan, sehingga dalam melaksanakan upaya perlindungan terhadap Hak Anak oleh 
Pemerintah harus didasarkan pada prinsip hak asasi manusia yaitu penghormatan, pemenuhan, dan perlindungan atas Hak Anak.

\section{Kesimpulan}

Bentuk perlindungan hukum terhadap hak asasi anak yang menjadi korban kekerasan dapat diberikan dalam bentuk represif yang dilakukan dengan cara sistematis, melalui serangkaian program, stimulasi, latihan, pendidikan, bimbingan shalat, permainan dan dapat juga diberikan melalui bantuan hukum yang dinamakan advokasi dan hukum perlindungan anak. Konsep perlindungan hukum terhadap hak asasi anak di masa yang akan datang harus melakukan law reform sistem perlindungan anak di Indonesia dengan tujuan untuk memberikan keadilan, kepastian, dan kemanfaatan terhadap anak di Indonesia khususnya sehingga dapat melindungi sekaligus menjamin hak-hak asasi anak yang menjadi korban kekerasan. Agar hukum perlindungan anak di Indonesia kedepan harus dapat benarbenar memberikan perlindungan terhadap hak asasi anak yang menjadi korban kekerasan, selanjutnya hukum perlindungan anak harus bebas nilai dari asas kemanusiaan yang bersumber dari hak asasi manusia.

Buku-Buku

\section{Daftar Pustaka}

Arief, Barda Nawawi, 1998. Beberapa Aspek Kebijakan Penegakan dan Pengembangan Hukum Pidana, Bandung: Citra Aditya Bakti.

-------, 2007, Masalah Penegakan Hukum dan Kebijakan Hukum Pidana dalam Penanggulangan Kejahatan, Jakarta: Kencana Prenada Media Group.

Atmasasmita, Romli (ed), 1997, Pengdilan Anak di Indonesia, Bandung: Mandar Maju.

Badriyah, Siti Malikhaun, 2016, Sistem Penemuan Hukum dalam Masyarakat Prismatik, Jakarta: Kencana.

Fatoni, Syamsul, 2015, Pembaharuan Sistem Pemidanaan Perspektif Teoritis dan Pragmatis untuk Keadilan, Malang: Setara Press.

Fuady, Munir, 2003, Aliran Hukum Kritis Paradigma Ketidakberdayaan Hukum, Bandung: Citra Aditya Bakti.

Fuady, Munir dan Sylvia Laura L. Fuady, 2016, Hak Asasi Tersangka Pidana, Jakarta: Kencana.

Hasibuan, Syafruddin (ed), tt, Penerapan Hukum Pidana Formal Terhadap Anak Pelaku Tindak Pidana Oleh Marlina dalam Bunga Rampai Hukum Pidana Dan Kriminologi Serta Kesan Pesan Sahabat Menyambut 70 Tahun Muhammad Daud, Medan: Pustaka Bangsa Press. 
Joni, Muhammad dan Zulchaina Z Tanamas, 1999, Aspek Hukum Perlindungan Anak dalam Perspektif Konvensi Hak Anak, Bandung: Citra Aditya Bakti.

Isra, Saldi, 2016, Hukum yang Terabaikan, Catatan Hukum Dua Tahun Pemerintahan Jokow-JK, Jakarta: Kompas.

Makarao, Mohammad Taufik, dkk, 2013, Hukum Perlindungan Anak dan Penghapusan Kekerasan dalam Rumah Tangga, Jakarta: Rineka Cipta.

Muladi, 1995, Kapita Selekta Hukum Pidana, Semarang: Badan Penerbit Universitas Diponegoro.

Nuraeny, Henny, 2011, Tindak Pidana Perdagangan Orang Kebijakan Hukum Pidana dan Pencegahannya, Jakarta: Sinar Grafika.

Prakoso, Abintoro, 2013, Pembaruan Sistem Peradilan Pidana Anak, Yogyakarta: Laksbang Grafika.

Rahardjo, Satjipto, 2006, Membedah Hukum Progresif, Jakarta: Kompas.

Rahayu, Derita Prapti, 2014, Budaya Hukum Pancasila, Yogyakarta: Thafamedia.

Simanjuntak, Nikolas, 2009, Acara Pidana Indonesia dalam Sirkus Hukum, Jakarta: Ghalia Indonesia.

Suyanto, Bagong, 2016, Masalah Sosial Anak, cetakan ketiga Jakarta: Kencana.

Waddong, Maulana Hassan, 2000, Pengantar Advokasi dan Hukum Perlindungan Anak, Jakarta: Gramedia Indonesia.

Waluyo, Bambang, 2017, Viktimologi Perlindungan Korban \& Saksi, Jakarta: Sinar Grafika.

Jurnal

Antoni, Anak-Anak Sebagai Korban Kejahatan Seksual Dari Orang Dewasa, dalam Jurnal Nurani Kajian Syariah dan Masyarakat, Volume, 15 No. 1. Juni 2015.

Hadi, A. "Kesehatan Reproduksi Pada Kurikulum Madrasah di Sumatera Selatan". An Nisa'a, 9 (1), 1-22. Retrieved from http://jurnal.radenfatah.ac.id/index.php/annisa/article/view/259

Hadi, A. (2017). "Posisi Wanita dalam Sistem Politik Islam Perspektif Fenomelogi”. An Nisa'a, 12 (1), 9-20. Retrieved from http://jurnal.radenfatah.ac.id/index.php/annisa/article/view/15

Mimi, Unbanunaek, dkk, Diversi Dalam Perlindungan Hukum Anak Yang Bermasalah Hukum Dalam Sistem Peradilan Pidana Anak, dalam jurnal MMH, Jilid 43 No. 2, April 2014.

Wisnubroto, Al, Tinjauan Kritis Terhadap Sistem Peradilan Pidana, Makalah pada Seminar Nasional yang diselenggarakan Fakultas Hukum Universitas Atma Jaya Yogyakarta Bekerja sama dengan FPKK (Forum Perlindungan Korban Kekerasan) DIY LP3NI (Lembaga Pemberdayaan dan Penguatan Pendidikan Nasional Indonesia) Kepolisian Daerah Daerah Istimewah Yogyakarta, 26 Maret 2013. 